DOI: https://doi.org/10.34069/AI/2021.47.11.21

How to Cite:

Yaremko, G., Ivanova, N., Mandrychenko, Z., \& Gorpyniuk, O. (2021). Conceptual foundations of systematization of crimes against the bases of national security. Amazonia Investiga, 10(47), 207-215. https://doi.org/10.34069/AI/2021.47.11.21

\title{
Criminal and legal protection of national security: Problems of systematization of crimes
}

\section{Кримінально-правова охорона національної безпеки: проблеми систематизації злочинів}

Received: November 1,2021

Accepted: November 30, 2021

\author{
Written by: \\ Galyna Yaremko $^{89}$ \\ https://orcid.org/0000-0003-4333-0424 \\ Natalia Ivanova ${ }^{90}$ \\ https://orcid.org/0000-0001-8693-3255 \\ Zhanna Mandrychenko ${ }^{91}$ \\ https://orcid.org/0000-0002-9114-3044 \\ Oksana Gorpyniuk ${ }^{92}$ \\ https://orcid.org/0000-0003-3110-6564
}

\begin{abstract}
The chief idea of criminal law is to protect the individual, society, and the state from criminal encroachment. Defined by the legislator in the field of protection - the basics of national security, life and health, public safety, environment, etc. are subject to comprehensive research to improve the effectiveness of criminal law protection, which is of great practical importance. The foundations of national security are a multifaceted construction that requires detailed analysis. This work is devoted to the study of the conceptual foundations of systematization of crimes against the foundations of national security of Ukraine as one of the fundamental aspects of the theoretical basis of the criminal law system. The work aims to study the conceptual foundations of the systematization of crimes against the foundations of national security of Ukraine. The subject of study: problematic aspects of systematization of crimes against the foundations of national security of Ukraine. The object of research: approaches to the systematization of crimes against the foundations of national security of Ukraine. The authors used the following methods: observation, generalization, analysis, synthesis, experiment, formalization. As a result of the study, the universal definition of national security, the feasibility of a system of crimes
\end{abstract}

Анотація

\footnotetext{
${ }^{89}$ Ph.D., Associate Professor of the Department of Criminal Law Disciplines, Lviv State University of Internal Affairs, Ukraine.

${ }^{90} \mathrm{Ph}$.D., Associate Professor of the Department of Legal Courses, Berdyansk State Pedagogical University, Ukraine.

${ }^{91} \mathrm{Ph} . \mathrm{D}$., Associate Professor of the Department of Criminal Procedure, Detective and Investigative Activities of the National University "Odesa Law Academy", Ukraine.

${ }_{92}$ Ph.D., Associate Professor of the Department of Criminal Law Disciplines, Lviv State University of Internal Affairs, Ukraine.
} 
against the foundations of national security of Ukraine, determined as an experiment to develop subgroups under Section I of the Special Part of the Criminal Code.

Keywords: bases of national security, national security of Ukraine, system of crimes against national security, crime.

\section{Introduction}

Today's conditions require the creation of a legal system that can respond effectively to potential threats. Preventing and combating crimes against the foundations of national security requires an effective theoretical legal framework. In this regard, criminal law must be constantly improved, including through the making of new scientific developments.

Crimes against the foundations of Ukraine's national security are the most dangerous acts that encroach on public relations, ensuring the protection of state security, the country's defense capabilities, the independence of the state, and its constitutional order. Criminal protection of these social relations is the key to the proper functioning of the state and its institutions.

The normative-legal system that regulates criminal-legal relations is the Criminal Code of Ukraine (CCU), which consists of the General and Special parts, which are organically connected. This connection is manifested through the same tasks facing criminal law, as well as the same principles enshrined in the Basic Law of the country - the Constitution, the CCU, and international acts. Norms of the General Part of the CCU with general and basic for criminal law, including the Special Part of the CCU (the SP CCU).

As part of the study of the conceptual basis of the systematization of crimes against the national system, it should be noted that the system of the SP CCU, which regulates these acts, is a classification of norms depending on the characteristics of generic objects of crime. This criterion has become a scientifically sound basis for the placement of crimes within specific sections of the SP CCU.

Thus, it can be argued that the SP CCU is of great importance because its rules provide protection of the most important social relations; it проведеного дослідження було визначено універсальне визначення національної безпеки, доцільність системи злочинів проти основ національної безпеки України, запропоновано в якості експерименту розробити підгрупи у рамках Розділу I Особливої частини ККУ.

Ключові слова: основи національної безпеки, національна безпека України, система злочинів проти національної безпеки, злочин.

embodies the principle of legality, which is manifested in the fact that the punishment and criminality of the act are clearly defined by the norms of the CCU, excluding analogy; norms, contain a specific corpus delicti, which allows you to quickly qualify the act.

Crimes against the foundations of Ukraine's national security are listed in Sect. I of the SP CCU. On the objective side, such crimes are committed mainly by action, on the subjective side - only with direct intent. Subjects of crimes against the foundations of national security of Ukraine may be physically sane persons who have reached 16 years of age at the time of the crime, as well as persons who have reached 14 years of age at the time of the crime (Article 112 and Article 113 of the CCU).

As rightly noted by Rubashenko (2013), the rules of criminal law are equally aimed at protecting all objects of criminal law protection. Since such objects as the state, society, and the individual are integrated into the objects of criminal law protection provided by different sections of the $\mathrm{CCU}$, the triad "man-society-state" in criminal law should be used not as a dividing scheme, but as the only unifying security mechanism.

\section{Theoretical Framework or Literature Review}

The information and analytical base of the study consist of the Constitution of Ukraine (Law 254K/96-VR, 1996), the CCU (Law 2341-III, 2001), as well as the Law of Ukraine "On National Security of Ukraine" (Law 2469-VIII, 2018), the Law of Ukraine "On Amnesty in Ukraine" (Law 392/96-VR, 1996), etc.

Art. 17 of the Constitution of Ukraine (Law 254K/96-VR, 1996) declares that the protection of the sovereignty and territorial integrity of Ukraine, ensuring its economic and information security are the most important functions of the 


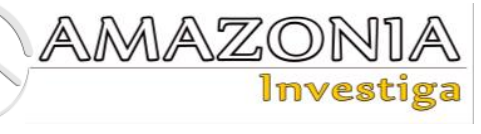

state, the business of the entire Ukrainian people. Besides, the CCU of Ukraine (Law 2341-III, 2001) contains a systematic list of crimes that infringe based on national security, as well as sanctions for committing such crimes.

The Law of Ukraine "On National Security of Ukraine" (Law 2469-VIII, 2018) defines the foundations and principles of national security and defense, goals, and basic principles of public policy that will guarantee society and every citizen protection from threats.

The Law of Ukraine "On Amnesty in Ukraine" (Law 392/96-VR, 1996) regulates the principles of the application of amnesty in Ukraine, including the provision on persons convicted of crimes against the foundations of national security of Ukraine. The amnesty cannot be applied to the latter.

The following scholars have studied the systematization of crimes against the foundations of national security: Stachitsa, and Tatsia (2010), Sukhonos, Bilokin, and Sukhonos (Jr.) (2020), Matviychuk (2013), Dudorov and Khavronyuk (2014), Vecherova (2015), Dzioban (2007), Bantishev, Zozulya, and Kuzmin (2009), Chornyi (2013ab), Chuvakov (2017), Pluzhnik (2013), Lesyak and Kushpit (2018), Zavada (2016), Baranin (2019), Dyakov, Ignatov, and Karpushin (1988), Rubashenko (2013).

In researching the issue of conceptual approaches to the systematization of crimes against the foundations of national security, the basic materials are contained in books on criminal law. Books of the following authors were used in this work: Stachitsa, and Tatsia (2010), Sukhonos, Bilokin, and Sukhonos (Jr.) (2020), Navrotsky (2000), Dudorov and Khavronyuk (2014), Pluzhnik (2013), Baranin (2019). These materials contain such concepts as the peculiarities of the construction of the SP CCU (Law 2341-III, 2001), reveal the content of each section of the SP CCU and each crime. Abstracts of lectures in a concise form reflect the most important issues of the discipline "Criminal Law of Ukraine".

Scholars articles used:

- $\quad$ "Some controversial issues of structuring the SP CCU and prospects for its further improvement" (Vecherova, 2015). The work highlights the problematic aspects of structuring the Special Part of the CCU, contains an analysis of the sequence of placement of the section of the Special Satin of the $\mathrm{CCU}$;

- National Security of Ukraine: Conceptual Principles and Worldview" (Dzioban, 2007). The work is devoted to the study of national security in the cultural-historical, axiological, ontological, structuralfunctional, and international dimensions. The essence of the key categories of the security sphere is explored through the prism of the intersubjective philosophical paradigm;

- "Criminal liability for crimes against the foundations of national security of Ukraine ("qualification problems") (Bantishev, and Shamara, 2014). Research and practice of criminal-legal counteraction to crimes against the foundations of national security of Ukraine are analyzed. The work contains, among other things, theoretical material on the conceptual apparatus of the national security of Ukraine;

_ $\quad$ "Crimes against the foundations of national security: the concept and general characteristics" (Matviychuk, 2013). The research is devoted to the general characteristics of crimes against national security, analyzed the conceptual apparatus, developed a systematic approach to studying the phenomenon of national security and its consideration as socially dangerous acts that encroach on relations arising in the protection of national security of Ukraine from internal and external threats;

- $\quad$ "Problems of the concept of crimes under Sect. I of the SP CCU" (Chornyi, 2013ab). The provisions of the general theory of security and criminal law on the understanding of national security and its components, as well as the Law of Ukraine "On Fundamentals of National Security of Ukraine" (repealed) and the CCU, are studied.

- $\quad$ "General characteristics and types of crimes against the foundations of national security" (Lesyak, \& Kushpit, 2018). The criminal legislation devoted to crimes against the foundations of national security of Ukraine is analyzed, the problem of classification of these crimes and their concepts is considered;

- $\quad$ "The system of crimes that encroach on the interests of Ukraine in the field of state security" (Zavada, 2016). The general characteristic of crimes against bases of national security is given, debatable questions of placement of such crimes in $\mathrm{CCU}$ are considered, the expanded list of the 
crimes encroaching on bases of national security of Ukraine is offered;

Despite a large number of opinions on determining the place of crimes against the foundations of national security of Ukraine in the system of criminal-legal protection, the systematization of these crimes remains open and needs to be improved.

\section{Methodology}

Modern science has come to understand the methodology of scientific research as a set of methods of cognition of an object and as a general theory of the method. In this regard, the methodology performs the following functions: it allows to establish ways to obtain scientific knowledge, provides comprehensive information, allows you to create a system of scientific information based on objective facts and logical-analytical tools of scientific knowledge.

The following methods were used to study the issues of conceptual approaches to the systematization of crimes against the foundations of national security:

1) observation: the theoretical aspects security are purposefully studied. Components of the method, such as unambiguous design and objectivity, helped to clearly adhere to the objectives of the study. The cognitive result of observation is a description. Thus, the paper describes the general characteristics of crimes against the foundations of national security of Ukraine, in particular, the subject and object of the crime, the subjective and objective parties;

2) experiment: allows assuming possible positive results, setting such conditions, which do not currently exist in the object under study. Thus, it was proposed to change the system of crimes against the foundations of national security of Ukraine by allocating certain subgroups in Sect. I of the SP CCU;

3) formalization: the reflection of meaningful knowledge in symbolic form.

4) analysis: the division of the object into constituent parts to study them independently. Thus, the content of the studied object is consistently revealed by defining the conceptual apparatus, research of existing scientific approaches to the systematization;

5) synthesis: combining different parts of the object under study into a single whole. Conclusions were made on the most appropriate understanding of national security and the relevant system of crimes, the criterion for distinguishing between crimes enshrined in sections of the SP CCU;

6) generalization: the process of establishing the general properties and characteristics of objects. The properties of the generic object of crimes against the foundations of national security of Ukraine have been studied, various positions of scholars on the systematization of crimes have been collected both in the SP CCU and in Section I.

\section{Results and Discussion}

To properly organize the fight against crime, it is necessary to identify acts that are legally appropriate to recognize as crimes, as well as to determine the penalties that may be imposed by a court on behalf of the state for committing such acts. Such definitions are made based on the provisions of criminal law and are expressed in the norms of the SP CCU of Ukraine.

The analysis of a SP CCU shows the systematization of crimes in it on the basis of the generic object of corpus delicti, which has great codifying significance. Thus, during the adoption of a new law establishing criminal liability for a particular crime, it is included in the relevant section of the CCU, depending on the characteristics of its generic or direct object (Stachitsa, \& Tatsia, 2010). The generic object of crimes against the foundations of national security is public relations to protect the foundations of national security of our country.

It is the criterion of social danger that underlies the construction of the SP CCU. It is also possible to highlight the basic principles of construction of the SP CCU. They are (Sukhonos, Bilokin, \& Sukhonos (Jr.), 2020):

- the order of location of crimes in sections according to their public danger;

- unity of direct and tribal objects of crimes;

- $\quad$ and the value of public relations protected by law.

In the scientific literature, there are many opinions about the sequence of sections of the SP CCU. Thus, Navrotsky (2000) argues for the need for such a sequence of blocks of crimes by the criterion of public danger: first place a section on crimes against the interests of the individual, then - on crimes against the interests of society, and finally - on crimes against the state. 


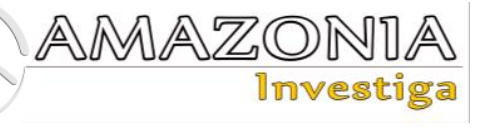

Dudorov and Khavronyuk (2014) believe that the SP CCU should contain the following blocks: criminal offenses against human and civil rights and the family; criminal offenses against the public interests of man, society, and the state; criminal offenses against national security and interests of the state, international law.

The basic principles must be taken into account in the legislative consolidation of norms (Art. 3 of the Constitution of Ukraine, Art. 1 of the CCU). However, the sequence of sections of the SP CCU somewhat contradicts the above provisions. The logic of the legislator in structuring the sections of the Special Part is explained by the fact that to protect people and their rights, the state must be viable and protect itself from criminal encroachment in the first place.

Referring to the international experience of structuring criminal offenses, it should be emphasized that the protection of human rights is still in the first place (CCU of Austria, Armenia, Kazakhstan (Law 226-V, 2014) (Serebrennikova, 2012).

Despite the theoretical and moral and political importance of emphasizing the role and importance of a section of the SP CCU, which combines certain crimes, the main thing is the effectiveness of the rules and their application.

According to Vecherova EM, among the crimes enshrined in the CCU, the most serious are crimes against peace, security of mankind and international law, war crimes, and crimes against national security, as these sections contain the largest number of serious and especially serious crimes (Vecherova, 2015). Following to Art. 4 of the Law of Ukraine "On Amnesty in Ukraine" (Law 392/96- VR, 1996), the application of amnesty to persons convicted of their commission (namely, the commission of particularly dangerous crimes against the foundations of national security of Ukraine) is not allowed. This justifies the legislator in highlighting crimes against the foundations of national security as one that requires priority protection.

The legal basis for the protection of the national security of Ukraine is the Constitution of Ukraine (Article 17), Law of Ukraine "On National Security of Ukraine" (Law 2469-VIII, 2018) (paragraph 9, part 1 of Article 1), CCU (Sect, I of the SP CCU).
Regarding the concept of national security, in the literature, you can find the idea of considering this concept as a degree of protection of interests not only of the state from external and internal threats but also the interests of the individual and society. It is also possible to add to this definition that national security is an indicator of the ability of society and the state to contain or eliminate internal and external threats to national sovereignty, territorial integrity, social order, economic development (Dzioban, 2007).

The science of criminal law defines the concept of crimes against national security as a socially dangerous act characterized by an act or omission committed with the direct intent of a sane individual who has reached the age of criminal responsibility and encroaches on the state and social order of Ukraine, its sovereignty, political system, inviolability , territorial integrity, defense capability, information and economic security, as well as national security in the fields of ecology and military armaments (Bantishev, \& Shamara, 2014); defined by the CCU of Ukraine, as well as committed with direct intent and special purpose, socially dangerous acts that encroach on relations arising in the field of protection of national security of Ukraine from internal and external threats (Matviychuk, 2013); jointly dangerous, illegal, guilty and punishable acts that cause harm or threaten to cause such harm to the external and internal security of the state, committed by the subject of the crime (Chornyi, 2013b). Chuvakov (2017) believes that such crimes are socially dangerous acts aimed at weakening or undermining the social order of Ukraine.

The system of crimes against national security is a structure of lawfully located and functioning elements that encroach on the protection of state sovereignty, territorial integrity, democratic constitutional order, and other national interests of Ukraine from real and potential threats.

The problem of the systematization of crimes against the foundations of national security is due to the lack of common approaches in the classification of these crimes. The legislator has grouped the crimes in Section I of the SP CCU (Article 109 - 114-2).

We can settle that it is appropriate to systematize the above crimes in one section through a common generic object (the basis of national security of the state in its various spheres), the objective side (actions or inaction), the subject (general and special subject). The immediate object and the subjective side of crimes against 
the foundations of national security have slightly different types of specificity within the sphere of the generic object. Thus, the motives of such crimes are of criminal law significance mainly as mitigating or aggravating circumstances. In this regard, Pluzhnik (2013), depending on the main direct object of crimes against the foundations of national security of Ukraine divides into three groups:

1) against the foundations of national security in the political sphere: actions aimed at forcible change or overthrow of the constitutional order or the seizure of state power (Article 109); encroachment on the territorial integrity and inviolability of Ukraine (Article 110); encroachment on the life of a statesman or public figure (Article 112);

2) against the foundations of national security in the information, economic, scientific, technological, and military spheres: treason (Article 111), espionage (Article 114);

3) against the foundations of national security in the economic, environmental, and military spheres: sabotage (Article 113).

Lesyak and Kushpit (2018) came to the conclusion of an inexhaustible list of crimes contained in Section I of the SP CCU. This conclusion was made on the basis of the analysis of scientific works of such authors as Chornyi, Zavada, who chose the object of criminal protection as the basis for the division of crimes against the national security of Ukraine. Thus, Zavada (2016) identifies the following types of these crimes:

1) crimes related to the intelligence and subversive activities of foreign intelligence services;

2) crimes that encroach on state territorial integrity and sovereignty;

3) crimes that encroach on the economic sphere of Ukraine;

4) crimes that encroach on the scientific and technical potential of Ukraine;

5) crimes that encroach on the defense sphere of Ukraine;

6) crimes related to encroachment on the rights and freedoms of citizens of Ukraine;

7) crimes related to the threat of corruption in public authorities and local governments;

8) criminal activity against the peace and security of mankind;

9) the threat of the spread of international terrorism;

10) threat of terrorist use of nuclear facilities on the territory of Ukraine;
11) illegal import of weapons, explosives, ammunition, and means of mass destruction into the territory of Ukraine;

12) attempts to create and operate illegal paramilitary armed organizations;

13) manifestations of separatism

It should be remarked that some types of crimes within the above system are subject to detailed analysis to create an objective basis for their inclusion in crimes against the foundations of national security of Ukraine. Thus, it is controversial to include crimes that infringe on human rights and freedoms in the system of protection of national security of Ukraine, in particular, in the group of crimes of Section I of the SP CCU. Based on the generic object of the crime as a classification criterion defined for crimes against the foundations of national security, namely the foundations of national security in various spheres, human rights and freedoms can be protected in the national security system of Ukraine only under Art. 110 of the CCU (Encroachment on the territorial integrity and inviolability of Ukraine). However, in general, the rights and freedoms of the individual as a collective concept in terms of reference to the protection of national security should be protected objects under other sections of the SP CCU.

It is also doubtful that such acts as crimes against the peace and security of mankind and the threat of the spread of international terrorism are included in the system of crimes against the foundations of Ukraine's national security. In the first case, the CCU contains Chapter XX, entitled "Criminal Offenses against Peace, Security of Mankind and International Law. The generic objects of such crimes are peace, security of mankind, and international law and order. Acts that constitute the objective side of this category of crimes may be committed for a long time in the territory of one or more states. Therefore, it is possible to assume the expediency of classifying the crimes against peace and security of mankind highlighted by Zavadoyi, the threat of the spread of international terrorism in Chapter XX of the CCU.

All other types of crimes have the right to be included in the system of crimes against the foundations of national security of Ukraine.

According to Chornyi (2013a), the system of crimes against the national security of Ukraine is as follows: 


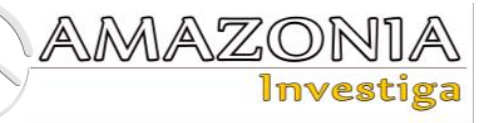

1) crimes that encroach on the constitutional order;

2) crimes related to human, economic, environmental, defense potentials of Ukraine;

3) crimes in the field of the order of acquisition, preservation, use, and dissemination of information in the possession of the state;

4) crimes related to the exercise of state power;

5) crimes in the field of external sovereignty.

It should be regarded that some scholars distinguish between crimes that encroach on internal and external security. Chuvakov (2017) singled out the features that distinguish these crimes (threat vector, presence of a foreign element, the presence of a specific object of encroachment). Dyakov, Ignatov, Karpushin (1988) among the crimes that encroach on external security include: treason, espionage, disclosure of state secrets, loss of documents containing state secrets; to crimes that encroach on internal security - encroachment on the life of a statesman or public figure, actions aimed at forcible change or overthrow of the constitutional order or the seizure of state power. This classification is adapted to the names of crimes under Ukrainian law.

According to Baranin (2019), external sovereignty is a subspecies of external state security, which is an integral part of the direct object of crimes against the foundations of national security.

6) crimes related to military service;

7) crimes in the sphere of stability of the budget system of Ukraine.

It is considered appropriate to comment on a selected group of crimes related to military service. The classification of military criminal offenses is based on the relevant direct object, which includes a certain aspect of the order of military service as a generic object of war crimes. Such types of objects are: the order of subordination, compliance with the statutory rules of relations between servicemen in the absence of relations of subordination, the order of passing and carrying out military service, etc. According to these types of criteria, crimes are grouped in Chapter XIX. Therefore, crimes related to military service should not be part of the system of crimes against the foundations of Ukraine's national security.

According to the subject, crimes against the foundations of national security are divided into those committed by a special subject and a general subject (Lesyak, \& Kushpit, 2018). The first group includes crimes such as treason and espionage, and the second group includes all other crimes in the field of national security.

This criterion for classifying the studied group of crimes as a sphere of action allows distinguishing the following types: crimes that encroach on relations that protect the foundations of national security in the political sphere, which include actions aimed at forcible change or overthrow of the constitutional order or seizure of state power; encroachment on the territorial integrity and inviolability of Ukraine; encroachment on the life of a statesman or public figure; crimes that encroach on relations that ensure the protection of the foundations of national security of Ukraine in the field of state sovereignty, territorial integrity and inviolability, defense, state, economic, scientific, technical and information security of Ukraine, which include treason and espionage; crimes that encroach on relations under conditions that ensure the protection of the foundations of national security in the economic, environmental and defense spheres. The last subgroup includes sabotage (Matviychuk, 2013). Thus, crimes against the foundations of national security are deservedly singled out by the legislator in Sect. I of the SP CCU. The scientific community has different approaches to the systematization of such crimes, due to the wide range of tasks facing the legislator in creating an effective theoretical basis for the protection of the foundations of national security of Ukraine.

\section{Conclusions}

Summarizing the above material, it is possible to draw the following conclusions:

- The legally established sequence of sections of the SP CCU provokes a lot of discussions. The main arguments in the expediency of priority protection of human life and health are the provisions of the Constitution of Ukraine, the General Part of the CCU, which put man, his life, and health (Article 17 of the Constitution of Ukraine, Section I of the CCU), and analysis of criminal norms of foreign countries, such as Armenia, Austria, Spain, Kazakhstan, Georgia;

- Crimes against the foundations of national security are socially dangerous acts (actions or omissions) that are committed with the direct intent of the subject of the crime, and encroach on state sovereignty, territorial integrity, democratic constitutional order, and other national interests of Ukraine; 
- the criteria for the classification of crimes against the foundations of national security are the subject of the crime, the object of criminal protection, the direct object, the scope;

- legislative enshrinement of crimes against the foundations of national security in Section I of the SP CCU is considered appropriate because of their greatest public danger;

- the possibility of developing a grouping of crimes against the foundations of national security into certain blocs, such as crimes related to intelligence and subversive activities of foreign intelligence services; crimes that encroach on state territorial integrity and sovereignty; crimes that encroach on the economic sphere of Ukraine; crimes that encroach on the scientific and technical potential of Ukraine; crimes that encroach on the defense sphere of Ukraine; crimes related to the threat of corruption in public authorities and local governments; the threat of terrorist use of nuclear facilities on the territory of Ukraine; illegal import of weapons, explosives, ammunition and means of mass destruction into the territory of Ukraine; attempts to create and operate illegal paramilitary armed organizations, etc.

\section{Bibliographic references}

Bantishev, O.F., \& Shamara, O.V. (2014). Criminal liability for crimes against the foundations of national security of Ukraine (qualification problems). Lugansk: Virtual reality.

https://er.dduvs.in.ua/bitstream/123456789/6 197/1/\%d0\%ba\%d1\%80\%d0\%b8\%d0\%bc\% $20 \%$ d0\%b2\%d1\%96\%d0\%b4\%d0\%bf.pdf

Bantishev, O.F., Zozulya, I.O., \& Kuzmin, S.L. (2009). General characteristics of modern criminal law of the Republic of Armenia. Legal Adviser, 6, 33-39.

Baranin, S. V. (2019). Synopsis of lectures on the subject "Criminal Law". Ministry of Internal Affairs of Ukraine. https://dduvs.in.ua/wpcontent/uploads/files/Structure/library/stude nt/lectures/2020/kpk/12.pdf.

Chornyi, R.L. (2013a). Problems of the concept of crimes provided for in Section I of the SP CCU of Ukraine. Scientific Bulletin of Lviv State University of Internal Affairs. legal series, $2, \quad 346-357$. https://www.lvduvs.edu.ua/documents_pdf/v isnyky/nvsy/02_2013/13chrlchku.pdf
Chornyi, R.L. (2013b). The system of crimes against state security under the $\mathrm{CCU}$ of Ukraine. University scientific records. Journal of Khmelnytsky University of Management and Law, 1, 261-272.

Chuvakov, O. (2017) Criminal-legal counteraction to crimes against the foundations of national security of Ukraine: theory and practice. (Doctoral thesis). National Academy of Sciences of Ukraine, Kyiv.

http://dspace.onu.edu.ua:8080/bitstream/123 456789/29968/1/\%d0\%b4\%d0\%b8\%d1\%81 $\% \mathrm{~d} 0 \% \mathrm{~b} 5 \% \mathrm{~d} 1 \% 80 \% \mathrm{~d} 1 \% 82 \% \mathrm{~d} 0 \% \mathrm{~b} 0 \% \mathrm{~d} 1 \% 8$ $6 \%$ d $1 \% 96 \%$ d $1 \% 8$ f.doc.pdf

Dudorov, O.O., \& Khavronyuk, M.I. (2014). Criminal Law. Kyiv: Waite. https://www.osce.org/files/f/documents/8/9/ 358166.pdf

Dyakov, S.V., Ignatov, A.A., \& Karpushin, M.T. (1988). Accountability for crimes against the state. Moscow: Legal literature.

Dzioban, O.P. (2007). National security of Ukraine: conceptual principles and ideological meaning. Kharkiv: Maidan.

Law 226-V, CCU of the Republic of Kazakhstan. Verkhovna Rada of Ukraine of July 3, 2014. https://online.zakon.kz/Document/?doc_id=3 1575252

Law 2341-III, CCU of Ukraine. Verkhovna Rada of Ukraine of April 5, 2001. https://zakon.rada.gov.ua/laws/show/234114\#Text

Law 2469-VIII, On National Security of Ukraine. Verkhovna Rada of Ukraine of June 21 , 2018. https://zakon.rada.gov.ua/laws/show/246919\#Text

Law $254 \kappa / 96-V R$, Constitution of Ukraine. Verkhovna Rada of Ukraine of June 28, 1996. https://zakon.rada.gov.ua/laws/show/254\%D 0\%BA/96-\%D0\%B2\%D1\%80\#Text

Law 392/96-VR, On Amnesty in Ukraine. Verkhovna Rada of Ukraine of October 1, 1996.

https://zakon.rada.gov.ua/laws/show/392/96$\% \mathrm{D} 0 \% \mathrm{~B} 2 \% \mathrm{D} 1 \% 80 \#$ Text

Lesyak, N.I., \& Kushpit, V.P. (2018) General characteristics and types of crimes against the foundations of national security. Legal Scientific Electronic Journal, 6, 287-289. http://www.lsej.org.ua/6_2018/80.pdf

Matviychuk, V.K. (2013). Crimes against the foundations of national security: concept and general characteristics. Legal science, 9, 80-87.

Navrotsky, V.O. (2000). Criminal law of Ukraine. Kyiv: Knowledge. 


\section{AMAZONIA \\ 1nvestiga}

Pluzhnik, O.I. (2013). Criminal law of Ukraine. Special part (lecture notes). Odessa: ODUVS. http://org2.knuba.edu.ua/pluginfile.php/7410 2/mod_resource/content/1/\%D0\%9A\%D1\% $80 \% \mathrm{D} 0 \% \mathrm{~B} 8 \% \mathrm{D} 0 \% \mathrm{BC} \% \mathrm{D} 1 \% 96 \% \mathrm{D} 0 \% \mathrm{BD}$ $\% \mathrm{D} 0 \% \mathrm{~B} 0 \% \mathrm{D} 0 \% \mathrm{BB} \% \mathrm{D} 1 \% 8 \mathrm{C} \% \mathrm{D} 0 \% \mathrm{BD} \%$ D0\%B5\%20\%D0\%BF\%D1\%80\%D0\%B0\% D0\%B2\%D0\%BE\%20\%D0\%9A\%D0\%BE $\% \mathrm{D} 0 \% \mathrm{BD} \% \mathrm{D} 1 \% 81 \% \mathrm{D} 0 \% \mathrm{BF} \% \mathrm{D} 0 \% \mathrm{~B} 5 \% \mathrm{D}$ 0\%BA\%D1\%82\%20\%D0\%BB\%D0\%B5\% D0\%BA\%D1\%86\%D1\%96\%D0\%B9\%20\% D0\%9E\%D1\%81\%D0\%BE\%D0\%B1\%D0 $\% \mathrm{BB} \% \mathrm{D} 0 \% \mathrm{~B} 8 \% \mathrm{D} 0 \% \mathrm{~B} 2 \% \mathrm{D} 0 \% \mathrm{~B} 0 \% 20 \% \mathrm{D}$ $1 \% 87 \% \mathrm{D} 0 \% \mathrm{~B} 0 \% \mathrm{D} 1 \% 81 \% \mathrm{D} 1 \% 82 \% \mathrm{D} 0 \% \mathrm{~B}$ $8 \% \mathrm{D} 0 \% \mathrm{BD} \% \mathrm{D} 0 \% \mathrm{~B} 0 \% 20 \% \mathrm{D} 0 \% 9 \mathrm{~F} \% \mathrm{D} 0 \%$ BB\%D1\%83\%D0\%B6\%D0\%BD\%D1\%96 $\%$ D0\%BA\%202013.pdf

Rubashenko, M.A. (2013). The place of crimes against the foundations of national security of Ukraine in the system of the SP CCU of Ukraine. Bulletin of the Ministry of Justice of Ukraine, 2 , 117-124. https://dspace.nlu.edu.ua/bitstream/1234567 89/10448/1/Rubashchenko_117-124.pdf

Serebrennikova, A. V. (2012). Classification of criminal acts under the laws of Germany,
Austria and Switzerland and its meaning. Business within the law, 5, 41-45. https://cyberleninka.ru/article/n/klassifikatsi ya-prestupnyh-deyaniy-po-zakonodatelstvugermanii-avstrii-i-shveytsarii-i-eeznachenie/viewer

Stachitsa, V.V., \& Tatsia, V.A. (Eds.). (2010). Criminal law of Ukraine. Kharkiv: Pravo. https://library.nlu.edu.ua/POLN_TEXT/KNI GI-2010/UgolovPravoOsob.pdf

Sukhonos, V.V., Bilokin, R.M., \& Sukhonos, V.V. (Jr.). (2020). Criminal law of Ukraine. Sumy: University book. https://essuir.sumdu.edu.ua/bitstreamdownload/123456789/76320/1/Sukhonos_Kr umGpravo.pdf

Vecherova, E.M. (2015). Some controversial issues of structuring a SP CCU of Ukraine and prospects for its further improvement. Law and Society, 4(3), 178-183. http://pravoisuspilstvo.org.ua/archive/2015/4 _2015/part_3/32.pdf

Zavada, H. W. (2016). The system of crimes that encroach on the interests of Ukraine in the field of state security. National Legal Journal: Theory and Practice, (4), 152-157. 